\title{
“A LOS TOROS!”: AS TOURADAS EM FEIRA DE SANTANA (1893-1905)
}

\author{
Fábio Santana Nunes ${ }^{1}$
}

Recebido em: $17 / 11 / 2020$

Aprovado em: 18/12/2020

\begin{abstract}
Resumo: Almeja identificar e analisar os espetáculos tauromáquicos promovidos em Feira de Santana, Bahia, na transição do século XIX ao XX. Considerado o uso dos periódicos como fonte histórica, foram consultados jornais publicados em Feira de Santana e outras regiões no período. Nos espetáculos feirenses, foram identificados toureiros profissionais espanhóis e animais selecionados de fazendas da região. Existiram eventos que não fizeram diferenciação etária ou de gênero nos valores das entradas do espetáculo, porém ocorreu distinção social com a comercialização de variados tipos e valores de ingresso. Para atender as touradas feirenses, existiram arenas armadas provisoriamente em espaço já projetado, o hipódromo, ou em área aberta contígua ao traçado urbano orgânico, o Campo do Gado. Assim como em outros divertimentos que aportaram à cidade, o transporte ferroviário teve implicação decisiva na interiorização das touradas. Conclui-se que a fiesta de los toros se expressou na cidade como uma diversão mercantilizada, exibida de maneira esporádica por companhias tauromáquicas itinerantes. As práticas experimentadas não foram capazes de transformá-la em um divertimento tradicional na urbe.
\end{abstract}

Palavras-Chave: História. Estudos do Lazer. Touradas. Sertão. Feira de Santana.

\section{“¡A LOS TOROS!”: LAS CORRIDAS DE TOROS EN FEIRA DE SANTANA (1893- 1905)}

Resumen: El objetivo es identificar y analizar la tauromaquia en Feira de Santana, Bahía, en la transición del siglo XIX al XX. Teniendo en cuenta el uso de los periódicos como fuente histórica, se consultaron los publicados en Feira de Santana y otras regiones en dicho periodo. En dichas corridas se identificaron toreros profesionales españoles y reses seleccionadas de ganaderías de la zona. Se celebraron eventos sin distinción de edad ni género en el precio de las entradas, aunque sí hubo distinción social en la comercialización de diferentes tipos y precios de las mismas. Para las corridas de Feira de Santana se habilitaron ruedos provisionales en un espacio proyectado, el hipódromo, o en un área abierta contigua al trazado urbano orgánico, el

\footnotetext{
${ }^{1}$ Doutorando do Programa de Pós-Graduação Interdisciplinar em Estudos do Lazer - Universidade Federal de Minas Gerais (UFMG). Mestre em Educação - Universidade Federal da Bahia (UFBA). Professor no Curso de Educação Física da Universidade Estadual de Feira de Santana (UEFS). Membro do Grupo de Pesquisa em História do Lazer (HISLA/CNPq). E-mail: fsnunes@uefs.br. ORCID: https://orcid.org/0000-0001-6194-7562. Agradeço as contribuições ao texto das(os) professoras(es): Priscila Gonçalves Soares, Flávia da Cruz Santos, Maria Cristina Rosa, Igor Maciel Silva, Jederson Garbin Tenório e Luís Capucha.
} 
Campo do Gado. Al igual que para otros eventos de la ciudad, el transporte ferroviario fue decisivo para la organización de las corridas. Concluimos indicando que la corrida de toros se concibió como un espectáculo con ánimo de lucro, ofrecido de modo esporádico por compañías de tauromaquia itinerantes. Las celebraciones no lograron implantarse como fiesta tradicional en la ciudad.

Palabras clave: Historia. Estudios sobre ocio. Corridas de toros. Sertão. Feira de Santana.

\section{“A LOS TOROS!”: BULLFIGHTING IN FEIRA DE SANTANA (1893-1905)}

Abstract: The study aims to identify and to analyze bullfighting shows promoted in Feira de Santana, Bahia, in the transition from the $19^{\text {th }}$ to the $20^{\text {th }}$ century. Considering the use of journals as a historical resource, some research was done to newspapers that were published in Feira de Santana and other places nearby, during the mentioned time. At the trade fair shows, it was identified professional Spanish bullfighters and selected animals from local farms. There were events that did not require any rate related to age or gender for entrance prices; however, social distinction was identified in what it comes to different types and prices of the tickets. To support trade fair bullfights, there were mounted arenas temporarily at an intended space, the horse-race track; or in an outdoor area adjoining to the urban green perimeter, called Campo do Gado (Cattle Field). As in other entertainment events that contributed to the city, the railway had decisive implications to bullfighting interiorization. It is concluded that the fiesta de los toros was expressed in the city as a commercialized entertainment, sporadically exhibited by touring bullfight companies. The experienced practices were not able to make it a traditional urban leisure.

Keywords: History. Leisure Studies. Bullfighting. Sertão (Brazilian hinterland). Feira de Santana.

\section{Introdução}

Tauromaquia ainda é pouco estudada pelas pesquisas históricas brasileiras em campos do saber como, por exemplo, História, Educação e Estudos do Lazer. Conforma uma temática apaixonante, rica em conhecimentos, valiosa à história e memória das cidades, porém com uma quantidade ainda diminuta de escritos estruturados, um dos motivos pelo qual este artigo foi produzido. Então, vamos "a los toros!"”2

Existiram distintos modelos de organização das touradas no Brasil. O primeiro foi o Estatal, desenvolvido durante os períodos colonial e monárquico. Rio de Janeiro, São Paulo e Salvador desfrutaram desses divertimentos nesses períodos históricos, recebendo significativa influência dos costumes dos colonizadores portugueses. Momentos festivos da Coroa Portuguesa no Brasil como o casamento do Príncipe D. Pedro de Alcântara ou a aclamação de

\footnotetext{
${ }^{2}$ Expressão consagrada no mundo das touradas, muito utilizada pela imprensa brasileira na transição dos séculos XIX-XX, soava como uma convocação aos redondéis. Inspiramo-nos em Vieira (2014) e Melo (2017) que com essas ou outras palavras fizeram uso desse recurso linguístico.
} 
D. João VI eram patrocinados pelo Erário e comemorados, entre outras ações, com touradas (MELO, 2013a; SANTOS; MELO, 2014; ROCHA JUNIOR; MELO, 2016).

Também existiu o segundo modelo, o Empresarial, que teve como base o "mercado taurino" que se desenvolvia desde a primeira metade do século XVIII na Europa, quando as touradas relegaram seu status de nobre entretenimento e fortaleceram a versão popular dos eventos públicos com pagamento de ingressos (MARTÍNEZ, 2013). Esse formato avançou por toda a Península Ibérica, sul da França e parte latina do Continente Americano. Os eventos tauromáquicos profissionais "não foram um fenômeno vinculado ao atraso, muito pelo contrário", eles anunciavam "o que seria comercialmente o entretenimento no futuro", pioneiros de um tipo de divertimento (diríamos, predecessores) que, posteriormente, a sociedade de massas consolidaria como espetáculo esportivo (FEIJÓ, 2019, p. 10). As touradas durante algum tempo assumiram papel de esporte em parte da imprensa brasileira (ROCHA JUNIOR; MELO, 2016; DIAS, et al., 2019), por certo, dialogando com a sociedade da época, essa possível representação.

Esse modelo empresarial foi desenvolvido desde meados do século XIX na cidade do Rio de Janeiro e, principalmente, nas três últimas décadas do XIX e primeiras do XX, ganharam diversas regiões do País em capitais como Curitiba, Belém, Rio de Janeiro, Porto Alegre, São Paulo, Salvador, Belo Horizonte, entre outras (BAHLS, 1998; SARGES, 2008; MELO, 2009; KARLS; MELO, 2014; SANTOS; MELO, 2014; ROCHA JUNIOR; MELO, 2016; RODRIGUES, 2006). Esses estudos mostram touradas realizadas em distintos lugares: hipódromos, teatros, redondéis improvisados em praças públicas e lugares contíguos à zona urbana, bem como em praças de touros permanentes constituídas para este fim.

Também regiões interioranas vivenciaram experiências lúdicas tauromáquicas, contudo a literatura especializada traz apontamentos, como são os casos de Juiz de Fora (SOARES, 2010), Ouro Preto ${ }^{3}$ (BIBBÓ, 2017) e Alagoinhas (LIMA , 2018) ou apenas cita os municípios , pois não era o locus de suas análises: Rio Grande, Pelotas e Bagé (KARLS; MELO, 2014); Oliveira (AMARAL; DIAS, 2017); Itu, Taubaté, Tatuí e São Luiz de Paraitinga (SANTOS; MELO, 2014). Nesse sentido, indicamos que as touradas realizadas em cidades do interior, até o presente momento, se configuram de maneira tímida como objeto de estudo das pesquisas desenvolvidas no País.

Exemplificando, os esforços acadêmicos ainda não foram suficientes para mapear as Companhias de Tauromaquia existentes no Território brasileiro nos séculos XIX e XX. Quantas

\footnotetext{
${ }^{3}$ A cidade, no recorte temporal pesquisado, ainda era a capital da Província de Minas Gerais.
} 
eram? Seus atores e atrizes? Quem eram os empresários à frente delas? Operavam numa cidade ou região, ou percorriam outros lugares? Por quais cidades passaram? Existem outros pontos, ainda, que merecem respostas.

Empresas de toureio percorreram o Brasil. A companhia de Francisco Pontes é um bom exemplo, fazendo espetáculos de Porto Alegre à Bahia (MELO, 2017) ${ }^{4}$. Localizamos outra, "Companhia Hespanhola", formada por espanhóis e portugueses, desenvolvendo funções em todos os lugares que aportou. Mais de $6.000 \mathrm{Km}$ percorridos no Brasil, entre os anos de $1892 \mathrm{e}$ 1893, navegando pelo Oceano Atlântico e pelo Rio Amazonas, uma verdadeira saga! Passou pela Bahia, vinda do Rio de Janeiro, se deslocou para Pernambuco, em seguida para a província do Grão-Pará e por fim Manaus (CORREIO PARAENSE, n. 171, p.01, 27 nov. 1892; AMAZONAS, n. 141, p. 01, 08 jul. 1893). Um toureiro que participou de uma das funções durante esta "turnê" em Salvador seria o mesmo que poucos anos depois dirigiria uma das companhias que passaram pelas paragens feirenses.

Câmara Cascudo (2005, p. 107), tratando da gênese das vaquejadas no Brasil, menciona o predomínio das touradas no século XVIII em Portugal, ao assinalar que esse costume veio para o Brasil, "mas não se aclimatou no Norte". De fato, em muitas regiões brasileiras, a tauromaquia não se tornou uma tradição, porém exceções existiram, inclusive, no Norte e Nordeste brasileiros, que convencionalmente eram nomeados apenas "Norte" até o início do século XX. Por exemplo, o Colyseu Paraense, templo de grandes eventos taurinos inaugurado em 13 de maio de 1893, perdurou por mais de 20 anos na cidade de Belém - Pará tendo por vezes público aproximado de cinco mil espectadores (O DEMOCRATA, n. 107, p. 03, 13 maio 1893; ESTADO DO PARÁ, n. 1077, p. 04, 25 mar. 1914; SARGES, 2008; DIAS, et al., 2019).

Nesse sentido, os objetivos do texto são identificar e analisar os espetáculos tauromáquicos promovidos em Feira de Santana-BA, na transição do século XIX ao XX. O arraial de Sant'Anna dos Olhos d'Agua emancipou-se, político-administrativamente, em 1833, transformando-se em Vila de Santana da Feira, com território desmembrado do Munícipio de Cachoeira, ganhando status de "Cidade Comercial de Feira de Santana", em 1873; e, posteriormente, o nome atual, Feira de Santana (SILVA, 2000; MELLO; BRITO, 2018).

A posição dominante da vila na dinâmica comercial da região tornou-se possível pelas transformações sociais básicas sentidas pela população rural. Em 1860, a comercialização de

\footnotetext{
${ }^{4}$ A obra organizada por Victor Melo (2017), reúne, além de textos inéditos, vários artigos publicados que são mencionados neste estudo, a saber: Melo (2013a), Melo (2013b), Melo (2015), Santos e Melo (2014), Karls e Melo (2014), Rocha Junior e Melo (2016).

${ }^{5}$ Conservamos, nas citações diretas, as grafias em uso na época em que foram editados os textos.
} 
produtos agrícolas contribuiu bastante para a riqueza de Feira de Santana, refletindo o desenvolvimento de um sistema novo de ocupações. Nesse período, a sociedade feudal-pastoril e suas grandes fazendas produtoras de gado cederam lugar aos sítios pequenos, de uma só família, constituindo a classe dos pequenos lavradores a maioria da população do Município (POPPINO,1968).

Em 1889, possuía “[...] dentro do perímetro de décima urbana, 4.454 habitantes”, (MELLO; BRITO, 2018, p. 54). Neste mesmo período, segundo dados demográficos de 1890, a cidade da Bahia (como as pessoas se referiam a Salvador), possuía 174.412 moradores. (IBGE, 2010). No Recenseamento de 1920, no total de pessoas no "Distrito-Sede", 14.479 (BRASIL, 1926, p. 37), uma população citadina muito aquém dos centros urbanos da época. Até as duas primeiras décadas do século XX, provavelmente, quantitativo inferior a dez por cento da população se concentrava na Sede do Município e nas vilas circunvizinhas. "Acentuouse a tendência para urbanização" depois de 1920. (POPPINO,1968, p. 247).

A urbe local estava em inicial urbanização em 1920 e 1930, para alguns pesquisadores e memorialistas, longe, ainda, de marcadores objetivos que a distanciassem do mundo rural. Antes, não havia sistema de abastecimento, estradas de rodagem, escolas de nível secundário. Contava com um sistema de iluminação pública apenas nas ruas centrais, não durando a noite em sua íntegra. Poucas ruas calçadas (SILVA, 2000; LAGEDINHO, 2004; BOAVENTURA, 2006; OLIVEIRA, 2016). Outro elemento importante, de 1889 a 1930, a produção industrial fora considerada insignificante, com exceção do beneficiamento do fumo (POPPINO,1968).

Consultamos periódicos publicados em Feira de Santana nos séculos XIX e XX. Conforme Santos (2012), os periódicos, ao veicularem determinada visão da urbe, contribuíam para que esta imagem fosse se consolidando e, ao publicarem matérias sobre o comportamento de seus habitantes, as relações desses com os divertimentos, estabeleciam parâmetros daquilo que estaria de acordo com a "Feira civilizada" ou das condutas que deveriam ser abolidas. Trazemos, para uma melhor contextualização, detalhes destes noticiosos para, assim, compreender a importância deles para a historiografia local e a própria elaboração histórica citadina.

O Município e Gazeta do Povo circularam na última década do século XIX (OLIVEIRA, 2000). O Progresso principiou suas funções em junho de 1900 e encerrou seu expediente em 1909, pertencente a Alexandre da Silva Ribeiro. (CUNHA, 2013). Conforme também essa historiadora, A Folha do Norte ${ }^{6}$, ainda em circulação, configura-se uma das principais fontes

\footnotetext{
${ }^{6}$ Fizemos uso também do livro (MELLO; BRITO, 2018), trazendo os textos publicados na coluna "Crônica Feirense" (1923-1924) do jornal. As primeiras experiências embrionárias da coluna "Vida Feirense", tendo o
} 
para os historiadores que pesquisam Feira de Santana, fundado em 17 de setembro de 1909 pelo Coronel Tito Rui Bacelar (Intendente Municipal entre 1904-1906). Todos encontrados em formato digitalizado na Biblioteca Setorial Monsenhor Galvão no prédio do Museu Casa do Sertão em Feira de Santana.

O Propulsor, propriedade de Demetrio Ignacio Pires d'Araujo (O PROPULSOR, n.03, p. 03, 29 out. 1896) fundado em 15 de outubro de 1896, suspendeu sua publicação na cidade em 29 de agosto de 1909, instalando-se no município de São Felix (MELLO; BRITO, 2018). Tivemos acesso aos números iniciais até dezembro de 1901, em formato impresso, depositados no Instituto Geográfico e Histórico da Bahia em Salvador.

Adicionalmente os jornais ${ }^{7}$ depositados na Hemeroteca Digital da Biblioteca Nacional serviram de suporte. Com efeito, são consideradas recomendações no uso dos periódicos como fonte histórica, e seguidos alguns procedimentos para a análise destes impressos (LUCA, 2019).

\section{Mercantilização das diversões em Feira de Santana}

No último quartel do século XIX, percebe-se em Feira de Santana, guardadas as proporções, algo observado décadas antes no Rio de Janeiro. Maior estruturação de um mercado de entretenimentos, relacionado, entre outras coisas, à conformação de uma sociedade em processo de diversificação socioeconômica. A expansão e a heterogeneização dos divertimentos influenciaram maior vivacidade da cena pública e também foram influenciados por este contexto (KARLS; MELO, 2018). Nas localidades nas quais se desenvolveram esses elementos, as touradas mais vertiginosamente se organizaram (ROCHA JUNIOR; MELO, 2016).

Modalidades de diversões públicas do Brasil, em seus moldes modernos, datam de meados ou fins do século XVIII. Evidencia-se, contudo, uma significativa modificação no universo do lazer no século XIX, subordinando-se a organização e a oferta de atividades de lazer aos aparatos de uma "economia de mercado", assumindo "uma feição cada vez mais comercial.” (DIAS, 2018, p. 384 e 398). Alguns espaços-símbolos dos divertimentos comercializáveis já existiam, notadamente, um teatro e um hipódromo.

\footnotetext{
mesmo editor, Arnold Ferreira da Silva, intendente entre 1924-1927 e prefeito no final dos anos de 1950. A coluna trazia efemérides sobre a história da urbe. (POPPINO, 1968; MELLO; BRITO, 2018).

${ }^{7}$ Entre esses, reunidos em formato de livro, alguns números de diversos periódicos feirenses publicados de 1877 1888 (BRITO; OLIVEIRA, 2007).
} 
O Teatro Sant'Anna realizava eventos pelo menos desde abril de 1884 (FOLHA DO NORTE, n. 1607, p. 01, 27 abr. 1940). Santos (2012) usa a expressão “Espaço Multifacetado", referindo-se a essa casa de espetáculos exatamente pela diversidade de atividades ali realizadas. É lugar propício para práticas como apresentações teatrais, cinematográficas, de teatro-circo, concertos musicais ou mesmo Ilusionismo (O PROPULSOR, n.164, p. 01, 03 nov. 1899; $O$ PROPULSOR, n. 08, p. 04, 05 dez. 1896; O PROPULSOR, n.159, p. 01, 1899; O PROPULSOR, n.85, p. 01, 29 maio 1898).

Outrossim, o prado pertencente ao Jockey Club Feirense já era destacado na imprensa em setembro de 1890, sendo palco de "Grandes corridas" de turfe organizadas pela Filarmônica 25 de Março (MELLO; BRITO, 2018, p. 43). No ano subsequente, outras corridas de cavalo são relatadas na impressa.

Ampliam o entendimento defendido sobre a mercantilização do lazer na urbe feirense registros de outras práticas de diversão ocorridas em alguns distintos logradouros da cidade e mesmo organização de "Passeios de Recreio" para localidades vizinhas (MELLO; BRITO, 2018). Essas viagens juntamente às “Tocatas" e "Kermesses”, respectivamente, em praças e chácaras no espaço urbano feirense, eram promovidos pelas duas sociedades filarmônicas existentes no período, a 25 de Março e a Victória (O PROPULSOR, n.84, p. 02, 22 maio 1898; O PROPULSOR, n.78, p. 03, 10 abr. 1898). Uma das quermesses promovidas pela "25 de Março" em 1898, alcançou um público estimado de dois mil participantes (O PROPULSOR, n.65, p. 01, 09 jan. 1898). Podemos ter uma ideia do potencial público das touradas.

Os noticiosos também citam a realização de espetáculos circenses, por exemplo, uma "magnífica companhia zoológica" em 1882, o editor arremata que teríamos "alguns dias de divertimento." (O PROGRESSO, n.04, p. 02, 10 ago. 1882). Em meados de 1897, [...] em trem expresso, chegou a esta cidade uma companhia de circo" (O PROPULSOR, n. 35, p. 02, 12 de jun. 1897). Entre esses e outros divertimentos forjados ainda no final da centúria XIX, é possível constatar a importância do trem nesse processo de comercialização dessas práticas na cidade.

Existiram experiências de lazer em algumas cidades, fruto de oportunidades comerciais facilitadas muitas vezes pelo transporte ferroviário e também fluvial (SILVA, 2014; AMARAL; DIAS, 2017). No caso de Feira de Santana, um ramal da Estrada de Ferro Central da Bahia, inaugurado em dezembro de 1876. Seu trajeto findava na "Heroica Cidade de Cachoeira", assim chamada pelo papel de destaque na Independência da Bahia em 1823, totalizando $48 \mathrm{~km}$ entre essas duas urbes. E pela “[...] estreita colaboração com os serviços marítimos da baía de Todos os Santos", aproveitando-se de vapores ancorados no porto da urbe cachoeirana banhada pelo 
Rio Paraguaçu, a viagem da urbe feirense "para a Cidade do Salvador durava menos de sete horas". (POPPINO, 1968, p.197).

Tomando como indício a rota de partida de companhias de entretenimento que alcançaram Feira de Santana, indicada em algumas notícias mencionadas, ou seja, a cidade de Cachoeira, provavelmente as companhias tauromáquicas (assim como as demais empresas) devam ter utilizado esses meios de transporte nestes percursos.

Como veremos à frente, aponta-se a localização aproximada dos espaços de execução de touradas identificados por meio das fontes manuseadas (Figura 01). Representado pelo traçado de maior área, o Campo General Câmara, um grande descampado (1). Vemos o que seria a Rua ABC, depois designada Avenida Sampaio, local do Prado Feirense (2) (FOLHA DO NORTE, n. 280, p. 01, 26 jul.1914), a “[...] 5 minutos da praça do comercio.” (3) (FOLHA DO NORTE, n. 2036, p. 02, 17 jul.1948). Pela imagem, é possível situar, a estação ferroviária (4) e, ainda, o que viria a ser a Praça Padre Ovídeo ${ }^{8}$ (5) ao lado da Igreja Matriz (identificada por cruz) e o Theatro Sant'Anna (6).

Figura 01 - Planta da cidade de Feira de Santana em 1878

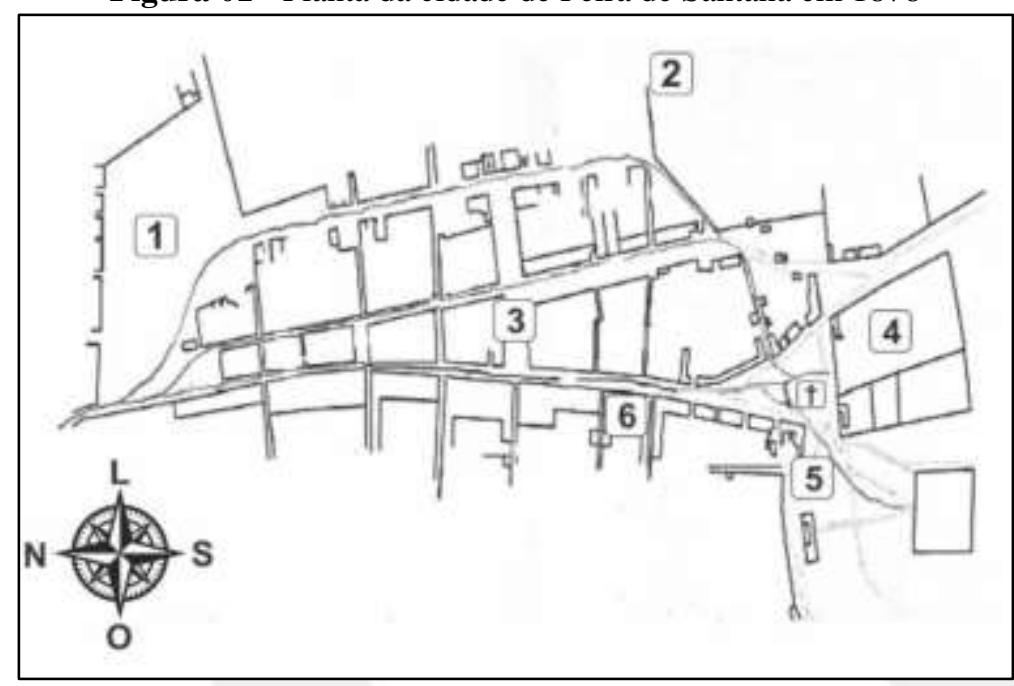

Fonte: Costa (2013. p. 60), com adaptações.

Com base nesses indícios, entendemos que possivelmente as experiências de divertimentos realizadas em Salvador, entre essas, as tauromáquicas, dialogavam com as realizadas no interior do Estado, aproveitando-se dos seguintes elementos: estruturas de transporte que ligava a Capital às cidades interioranas baianas (transporte marítimo e ferroviário); estruturas e mercado de entretenimento (teatro e hipódromo) consolidado ou em

\footnotetext{
${ }^{8}$ Antigo Largo da Matriz, um espaço mais centralizado. Tratando de recorte posterior à pesquisa, o memorialista Antônio Moreira Ferreira, conhecido como "Lajedinho" traz de suas lembranças (conversa informal com o autor) touradas nesse local ainda executadas na primeira metade do século XX, anos 1930 e 1940.
} 
processo; estruturas citadinas auxiliares (restaurantes e hotéis) que pudessem colaborar para a estadia da companhia; e potencial assistência (homens, mulheres e crianças) sedenta por novidades e com recursos financeiros para afluência aos espetáculos.

\section{As touradas feirenses do final do século XIX}

É importante contextualizar, política e culturalmente, o que se passava na sociedade brasileira e as reflexões deste momento em Feira de Santana. A mudança de regime político, inaugurando um período republicano, apresentou desdobramentos que resvalam no processo de modernização e progresso do País. Algumas transformações eram sentidas de maneira objetiva no traçado urbano, uma preocupação crescente com calçamento e arborização das ruas, criação de novéis espaços de sociabilidade como "novas e espaçosas praças", inauguração da primeira biblioteca pública do interior da Bahia em novembro de 1890 e a própria construção do "hyppodromo para nossas diversões" destacado ao longo do texto (MELLO; BRITO, 2020, p. 16). Todas estas mudanças, contudo, não apagaram as características rurais presentes, pois ainda era um povoamento muito distante do grande centro urbano que se transformara em meados do século XX.

No material pesquisado não foram encontradas referências às touradas na cidade de 1877 a 1892, fato que se modifica em 1893 quando uma propaganda divulgada na imprensa sinaliza a venda de artigo utilizado nos dias de divertimentos públicos, como as corridas de cavalo e as touradas. A Comercial Cesar \& C. com o título "Touradas" (Figura 2), fazia uma chamada de "um lindo guarda sol [...]" que estava sendo negociado.

Este é um indício de que, talvez, esta prática pudesse ocorrer dentre o rol das diversões citadinas feirenses no segundo semestre de 1893. Outra possibilidade plausível seria que as touradas estivessem sucedendo na Capital baiana ou em Cachoeira, mobilizando parcela dos feirenses abastados que deveriam estar a caráter, afinal o uso dos guarda-sóis nestes divertimentos - além de compor a vestimenta feminina da época junto com o chapéu e o leque, elementos que permitiam um "equilíbrio para a estética das roupas." (XIMENES, 2004, p. 47) - se justificava devido ao sol e ao clima quente ou mesmo momentos chuvosos. 
Figura 2- Propaganda de guarda-sóis para uso nas touradas

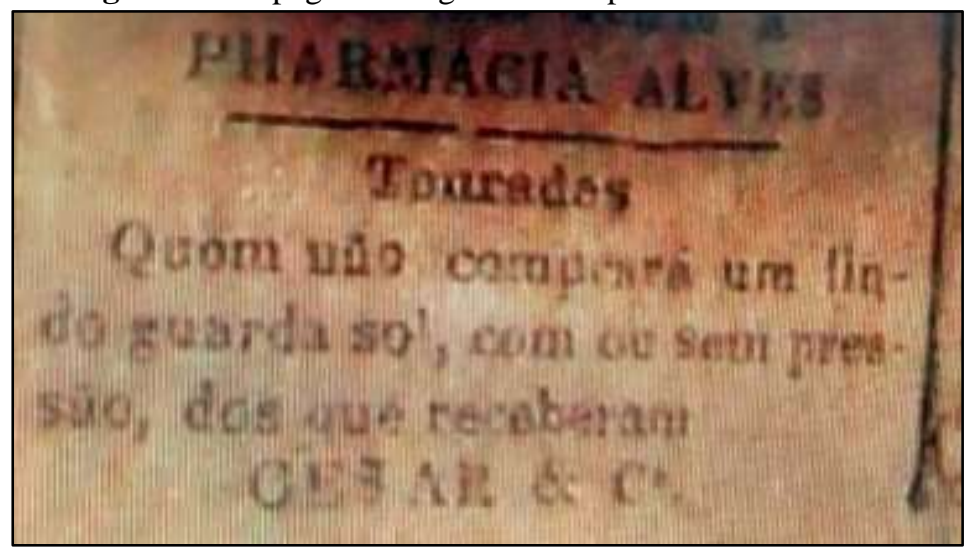

Fonte: O MUNICÍPIO, n. 132, p. 02, [s. d.], 1893.

As touradas brasileiras do final do século XIX e início do XX não eram eventos rápidos, transcorriam frequentemente no turno vespertino, muitas ao ar livre, terminando, em certas vezes, com os últimos raios solares ${ }^{9}$. Em Feira de Santana, uma fonte indica esta mesma dinâmica, porém alguns anos depois: "O Espectaculo dará começo ás 4 horas da tarde." (O PROPULSOR, n.06, p. 04, 20 nov. 1896).

A existência de apresentações tauromáquicas pôde ser mais bem percebida a partir dos meses de novembro e dezembro de 1896, quando o seguinte anúncio foi publicado na imprensa e persistiu por três finais de semana: "TOURADAS! COMPANHIA TAUROMACHICA". Entre outras informações estava uma convocação: “AO HIPPODROMO”. A estreia foi em um domingo, 22 de novembro, possivelmente, uma das primeiras vezes que a execução deste tipo de divertimento fora anunciada na cidade (O PROPULSOR, n.06, p. 04, 20 nov. 1896). Uma pequena nota no Folha do Norte novamente na coluna "Crônica Feirense" traz a "Estréia da companhia tauromachica da empresa Signes, Cortez e C.” (MELLO; BRITO, 2018, p. 50). Certamente a mesma empresa que trabalharia no prado feirense, visto ambas serem anunciadas para o mesmo dia e também porque o nome "Cortez", provavelmente sofreu um aportuguesamento para "Cortes" no cartaz da tourada (Figura 3), algo muito comum naquele tempo.

O acontecimento não trazia a representação de prática esportiva exibida na imprensa, identificada, exemplificativamente, no Rio de Janeiro, Belém e Salvador na transição dos séculos XIX ao XX (MELO, 2009; DIAS et al., 2019; ROCHA JUNIOR; MELO, 2016). Esse

\footnotetext{
${ }^{9}$ Existiram touradas em horários noturnos. Arenas iluminadas com lampiões a gás ou energia elétrica (KARLS; MELO, 2014; SANTOS; MELO, 2014; DIAS, et al., 2019).
} 
divertimento se aproximava das apresentações cênicas ${ }^{10}$, porém realizada em outro espaço de espetáculos: o Jockey Club Feirense.

Figura 3 - Cartaz da tourada na cidade de Feira de Santana

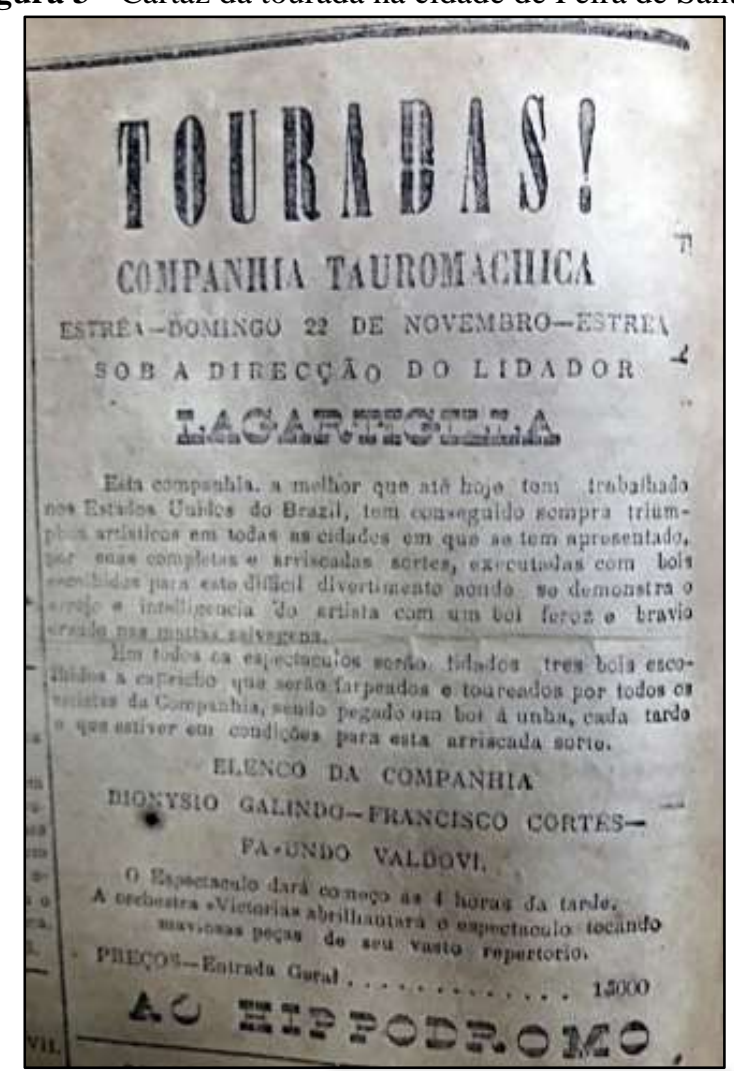

Fonte: O PROPULSOR, n. 06, p. 04, 20 nov. 1896.

Como vimos, as touradas foram acolhidas por vezes nos espaços já projetados dos hipódromos ligados originalmente, mas não exclusivamente, à realização de corridas de cavalo (ROCHA JUNIOR; MELO, 2016; DIAS, et al., 2019). Eles possuíam estrutura semelhante às arenas de tauromaquia, no entanto com uma espacialidade diferente, visto não apresentarem arquibancadas circulares comuns aos redondéis destinados às touradas. Tomando as experiências do turfe no Rio de Janeiro e em Salvador, identificamos elementos correntes aos prados, que possuíam: pista de corridas, encilhamento, arquibancadas, banheiros, vestiários, depósito para equipamentos e baias para os animais com locais para água substituindo o touril (usual às praças de toureio). Restaurantes e/ou botequins para o convívio social eram, também, espaços frequentes (MELO, 2007; DIARIO DO POVO, n.17, p. 01, 24 maio 1889). Parte significativa dessa infraestrutura poderia ser disponibilizada nos dias dos eventos taurinos.

\footnotetext{
${ }^{10}$ Houveram ocorrências da tauromaquia em casas de espetáculos teatrais brasileiras (SANTOS; MELO, 2014; ROCHA JUNIOR; MELO, 2016).
} 
E qual a estrutura do Hipódromo Feirense? Talvez alguns dos elementos citados acima pudessem não existir, contudo há indícios de que parte deles se fazia presente. Por exemplo, uma notícia salientando os valores dos ingressos destinados à participação nos espetáculos turfísticos dizia da "arquibancada" e do "encilhamento" (FOLHA DO NORTE, n. 1492, 12 fev. 1938) ${ }^{11}$. Ficaram, então, evidenciadas duas estruturas tão caras a qualquer hipódromo. As arquibancadas permitiam que a assistência pudesse visualizar as corridas em toda sua extensão, e no contexto tratado, ver de uma posição superior às touradas evitaria possíveis acidentes acaso algum marruá bravo saísse do redondel, além de perceber melhor as sortes executadas. E o encilhamento, estrutura que tem como uma de suas finalidades, conforme o Dicionário do esporte no Brasil no final do século XIX e início do século XX, ser o local de preparação dos animais às corridas de cavalo (MELO, 2007). Parte dessa conformação poderia ser usada como touril e parte como um lugar de distinção, um camarote, haja vista, inclusive, os bilhetes serem mais caros nesse espaço.

Do mesmo modo servia ao turfe, poderia muito bem servir às touradas. O primeiro artigo do Estatuto do Jockey Club Feirense, entidade proprietária do prado construído, possivelmente, entre meados de 1889 e 1890, trazia, além do objetivo de organizar corridas de cavalos, a finalidade de "explorar n'esta cidade [...] quaesquer outras diversões lícitas." (DIÁRIO DA BAHIA, 07 nov. 1889, n. 249, p. 02).

Para promover essas permitidas diversões, não poderia faltar música de qualidade, considerada intrínseca à tauromaquia, executada nos redondéis desde a gênese da "arte taurina" (SARGES, 2008; SARGES, 2010). Assim como para as touradas, também para a cidade feirense, a musicalidade tinha um papel primordial nos divertimentos, as filarmônicas costumavam se fazer "presentes nos diversos eventos políticos, sociais, religiosos da urbe, animando a população" (SANTOS, 2012, p. 53).

Nesse sentido, uma filarmônica local bem conceituada possuidora de muitos adeptos e simpatizantes, a “orchestra Victoria”, estava na programação que abrilhantaria o espetáculo “tocando maviosas peças de seu vasto repertorio". (O PROPULSOR, n.06, p. 04, 20 nov. 1896). De alguma maneira, ter essa orquestra tocando no evento tauromáquico ampliava a possibilidade de sucesso, pois dialoga com a moralidade e os bons costumes tradicionais que, nesta época, associam as orquestras e a musicalidade clássica ao que deveria ser apreciado socialmente, destarte, contribuindo para a licitude do acontecimento. Atividades chanceladas ou mesmo com participação de outras entidades - nesse caso, uma associação musical - tinham

\footnotetext{
${ }^{11}$ A coluna "Vida Feirense", rememorando uma nota informativa do Gazeta do Povo, publicada em 12 de fevereiro de 1891.
} 
como um dos objetivos adicionais potencializar a arrecadação de recursos financeiros, aproveitando-se do prestígio dessas instituições. Acreditamos que não seria diferente com as touradas executadas nesta temporada em Feira de Santana.

As touradas feirenses não fizeram distinção etária ou de gênero nos valores das entradas do espetáculo em 1896 (O PROPULSOR, n.06, p. 04, 20 nov. 1896). Quatro anos antes, revelase a presença das senhoras e infantis nos toureios em Salvador (JORNAL DE NOTÍCIA, n. 3771, p. 01, 20 jun. 1892; JORNAL DE NOTÍCIA, n. 3791, p. 03, 16 jul. 1892). Mulheres e crianças nas touradas como espectadores é similarmente destacada em distintas localidades pelo País (MELO, 2017; DIAS et al., 2019). Nessa direção, assim como ocorreu em outras cidades, é possível conceber o registro de mulheres e crianças como espectadores das atividades tauromáquicas na urbe feirense.

Na primeira tarde de touradas em 1896, uma só modalidade de ingresso, "Entrada Geral 1\$000" (1 mil réis) (O PROPULSOR, n.06, p. 04, 20 nov. 1896), na época, com esse valor era possível comprar aproximadamente quatro litros de feijão e dois quilos de carne. Na segunda apresentação da companhia de touradas, acrescentou-se, apenas, outra modalidade: acessos preferenciais “com direito a assento 2\$000". (O PROPULSOR, n.07, p. 04, 29 nov. 1896). Era um indicativo de profissionalizaçao. Os tipos de ingresso desta prática cultural e seus respectivos valores variavam muito de cidade a cidade, dependiam da economia local dos lugares porque passavam e muito provavelmente da oferta e procura por estas e outras diversões. O mercado de entretenimento, ao mesmo tempo em que necessita se conformar com limitações econômicas e exigencias nos gostos locais, também gera demandas de consumo.

Padrão semelhante se repetia em outras localidades do País, variando, às vezes, os valores das entradas. Em São Paulo, os bilhetes foram vendidos por $2 \$ 000$ o mais caro e $1 \$ 000$ o mais barato, preços que perdurariam no decorrer do século XIX (SANTOS; MELO, 2014). No último decênio dessa centúria, as corridas de touros em Salvador, no Derby Club do Rio Vermelho, tínhamos desde espaços exclusivos como os camarotes, outros denominados "Sombra", até lugares destinados a ingressos mais populares ao "Sol". Dependendo da localização e faixa etária, as entradas eram vendidas por $\$ 500$ (quinhentos réis) a $15 \$ 000$ (quinze mil réis) por 5 bilhetes nos camarotes (JORNAL DE NOTÍCIA, n. 3791, p. 03, 16 jul.1892). Já os ingressos dos eventos taurinos no Colyseu Paraense, no mesmo período, variavam desde $2 \$ 000$ até $20 \$ 000$ para adquirir um camarote (SARGES, 2010), em uma Belém próspera economicamente devido ao Ciclo da Borracha, vivendo a Belle Époque Paraense (DIAS et al., 2019). 
Possivelmente por ser uma novidade, na urbe feirense, não existisse na época um debate local sobre serem estas atividades consideradas bárbaras ou não, pelo menos não localizamos esta controvérsia nas fontes. Provavelmente, do mesmo modo, se assemelhando à experiência tauromáquica desenvolvida em Porto Alegre (guardadas as proporções), ambas se afastavam do discurso de modernidade e progresso que entendia essas práticas aproximadas ao mundo das ruralidades como representações do atraso civilizacional. Essa tendência já se apresentava em outras cidades de alguns estados da Federação, notadamente, Rio de Janeiro (KARLS, MELO, 2014). Feira de Santana, neste período, ainda era um pequeno "empório" (OLIVEIRA, 2000). Essas tensões, eram traduzidas em possíveis regulamentações, muitas vezes, abarcadas em lei específica ou nos Códigos de Posturas Municipais. As touradas foram práticas proibidas ou regulamentadas, no decorrer do século XIX, em algumas cidades do País ${ }^{12}$. O código local, de dezembro de 1893, não faz menção diretamente a tauromaquia, contudo, no capítulo "DAS CONTRAVENÇÕES CONTRA A DECENCIA E BONS COSTUMES”, o artigo $33^{\circ}$ assevera: "Espancar animaes, dentro da cidade ou povoação. Pena $6 \$ 000$ de multa ou 2 dias de prisão." (O PROPULSOR, n.192, p. 03, 17 jun. 1900). Esta legislação provavelmente não gerou óbice à realização das funções.

Não foram apenas as corridas de touros, a "estrutura citadina" por completo tornava-se mais regulada, incluindo os demais divertimentos, um processo relacionado "tanto com as necessidades desencadeadas pelo crescimento dos municípios quanto com a melhor estruturação da burocracia governamental” (SANTOS; MELO, 2014, p. 47).

Apenas em julho de 1934, a legislação nacional proibiu as touradas, por meio do Decreto $n^{\circ} 24.645$ estabelecendo medidas de proteção aos animais em todo o território brasileiro (MELO, 2017). Estas práticas, no entanto, continuaram ocorrendo em algumas regiões ${ }^{13}$ até meados do século XX.

Como visto, comentamos diversos aspectos das touradas, a presença de musicalidade, seus preços, os turnos em que ocorriam, o público e as relações com as legislações locais, todavia, ainda não abordamos sobre os personagens principais desses espetáculos: os toureiros e os touros.

O elenco da quadrilha tauromáquica espanhola era formado, exclusivamente, por homens: Dionysio Galindo, Francisco Cortés e Fagundo Valdovi. Alguns municípios

\footnotetext{
${ }^{12}$ Sobre as proibições e controvérsias relativas à tauromachia em algumas capitais brasileiras, ver Melo (2017). Especificamente sobre os Códigos de Posturas Municipais, licenças públicas e a relação com as touradas, consultar Santos e Melo (2014), Vieira (2014) e Melo (2013b).

${ }^{13}$ Exemplo disso, são as touradas realizada na cidade de Manaus em 1960 (O CRUZEIRO, n. 15, p. 27, 23 jan. 1960).
} 
empreenderam touradas protagonizadas por mulheres. Pelo menos, desde de meados da centúria XIX, toureadoras desenvolvem trabalhos tauromáquicos no Brasil. (DIAS et al., 2019; KARLS; MELO, 2015; SANTOS; MELO, 2014; ROCHA JUNIOR; MELO, 2016). Contudo, não encontramos evidências da presença feminina na lida com os taurinos bravios em Feira de Santana.

Como bem destacado por Karls e Melo (2014, p. 357), "Valerá no futuro discutir mais profundamente a participação dessas mulheres nessas práticas.”. Com efeito, a temática das toureiras no Brasil merece ser desenvolvida em futuras pesquisas, pois elas estiveram à frente do seu tempo na luta por direitos e espaços tradicionalmente ocupados pela figura masculina.

O diretor da empresa, o espanhol ${ }^{14}$ Dionysio Galindo, alcunhado de Lagartigilla, foi algumas vezes citado principalmente na imprensa do Rio de Janeiro. Em março de 1892, localizamos uma das primeiras notícias em jornais brasileiros desse valente artista que, entre outros “corajosos toureiros hespanhóes" (GAZETA DE NOTÍCIAS, n. 80, p. 08, 20 mar. 1892) e portugueses, transpassou o Oceano Atlântico trazendo consigo as técnicas, a experiência e o profissionalismo dos divertimentos tauromáquicos. Em meados desse mesmo ano, ele ganhou igualmente destaque nos noticiosos de Salvador. Partícipe em outra empresa, uma "grande companhia hespanhola" (já mencionada), desenvolveu trabalhos na segunda função, tendo “assignalada a morte" de dois toiros (JORNAL DE NOTÍCIA, n. 3.778, p. 02, 30 jun. 1892). Outro periódico anunciava Lagartigilla lidando valentes animais ao público paulista, destacava o sucesso obtido por ele "nas principais praças de Touros da Hespanha, Montevidéo, Buenos Aires e ultimamente na capital federal" (O COMMERCIO DE SÃO PAULO, n. 2827, p. 04, 25 jan.1902) $)^{15}$.

O destaque dado aqui a esse personagem é no sentido de percebermos que as touradas feirenses estavam imersas em um contexto maior de realização dessa prática cultural, em franco desenvolvimento em algumas cidades pelo País, e os organizadores e também toureiros dessas funções não eram amadores locais, mas profissionais com passagens por diversos centros urbanos do Brasil e de outras partes do mundo. Durante esse período, existia, pois, uma espécie de circuito de eventos tauromáquicos ocorrendo pelo País, e Feira de Santana, não estava segregada deste movimento.

\footnotetext{
${ }^{14}$ Em uma rápida busca na Hemeroteca Digital Brasileira aparecem as seguintes nacionalidades dos toureadores que trabalharam no Brasil: muitos deles espanhóis e portugueses, mas, também, brasileiros e uruguaios. Segue o link: http://memoria.bn.br/hdb/periodico.aspx

${ }^{15}$ Percorreu, ainda no início do século XX, alguns redondéis brasileiros fazendo boas apresentações. Anos depois, 26 abril de 1909, outro periódico do Rio de Janeiro, o Jornal do Comercio, traz da "Hespanha", na primeira página, uma curta nota do dia anterior, desta forma somos surpreendidos com sua partida: "Colhido por um touro, veio a morrer o bandarilheiro 'Lagartigilla'."
} 
A companhia de Largartigilla anunciava conseguir, nas cidades por onde passou, “[...] sempre triumphos artísticos" "por suas completas e arriscadas sortes" ou seja, as técnicas de tourear, executadas com animais "escolhidos para este difícil divertimento aonde se demonstra o arrojo e inteligência do artista [...]” (O PROPULSOR, n.06, p. 04, 20 nov. 1896).

E de onde vinham os "touros", para compor o espetáculo feirense? Eram de raça brava de lide, importados da Europa ou de um outro país sul-americano, ou eram de explorações agropecuárias destinadas à produção de carne?

Em certas ocasiões, no Brasil, vinham das próprias regiões onde ocorreriam as apresentações das empresas taurinas (ROCHA JUNIOR; MELO, 2016). Esta dinâmica aconteceu em Feira de Santana, conforme um periódico. O organizador da tourada transitou em "[...] algumas fazendas do município" e adquiriu três "bravios touros" (O PROPULSOR, n. 07, p. 02, 29 nov. 1896).

Foram muito provavelmente animais de produção de carne, destinados à Feira de Gado, que acontece, semanalmente, há mais de dois séculos na cidade. Os que não eram vendidos para abate ficavam nas fazendas da região criados “à solta” para engorda. Até o final do século XIX, o gado dos criatórios baianos e das Províncias vizinhas "que eram levados para a feira, diferiam pouco daqueles que se criaram no Brasil nos tempos coloniais. Animais pequenos, com o couro duro, cabeças grandes e chifres compridos [...]" resultado dos cruzamentos de diversas espécies ibéricas e outras regiões europeias. Foram conhecidas como crioula, curraleira e caracu as que melhor se adaptaram na hinterlândia baiana (POPPINO, 1968, p. 156).

Mesmo sendo uma companhia composta por espanhóis em terras feirenses que, tradicionalmente, conforme Capucha (2017), exibe "corridas dos toiros" finalizadas com a morte destes, não há comprovação na programação. Vejamos: era anunciado que em todos os espetáculos seriam "lidados três bois escolhidos a capricho [...] farpeados e toureados por todos os artistas da Companhia", isto é, os animais deveriam ser toureados por todos os três toureiros anunciados. Este modelo exige que os touros sejam corridos várias vezes, reduzindo os custos altos na sua aquisição. De outro modo, faz decair em muito a qualidade das touradas. A "cada tarde" deveria um boi ser pegado "á unha" (O PROPULSOR, n.06, p. 04, 20 nov. 1896). Possivelmente essa sorte se misturava com outras muito praticadas na Península Ibérica: bandarilhas, saltos de garrocha (saltos com vara), quiebros, entre outras técnicas (CAPUCHA, 2017).

A moda portuguesa valoriza o toureio a cavalo, com embolação (chifres protegidos), com a apresentação dos forcados e sem a morte do touro no final, e a moda espanhola valoriza o toureio a pé, sem embolação e com a morte do touro no final (SANTOS; MELO, 2014). 
Evidenciamos, assim, como observado em outras pesquisas, uma mescla entre estilos de touradas espanholas e portuguesas. Haja vista a presença de animais pegados à unha, ou seja, forcados à moda lusitana, nas programações das touradas executadas na cidade. Não fica evidenciada a presença dos toureios a cavalo. Dito isto, é possível terem existido cavalheiros toureando, prática bem comum em outras touradas pelo País, onde o elemento cavalo esteve no espetáculo (MELO, 2017).

Para divulgar a segunda tourada, usaram o mesmo conteúdo propagandeado na semana anterior, inclusive, mantendo o termo "Estréa". Talvez pela decepção que o público passou "por não ter se encontrado touros bravios". Para sanar a problemática das "touradas de domingo passado", o jornal anunciava "ser bem reparada pela função anunciada para o dia de hoje" e que o diretor da empresa "lidador da tauromachica não tem poupado esforços" (O PROPULSOR, n. 07, p. 02, 29 nov. 1896) para dar uma qualidade exigida e necessária ao espetáculo. Seria neste sentido uma reestreia.

É possível também que o anuncio tenha sido reutilizado, talvez para economizar tempo e/ou dinheiro. Repetir anúncios era bastante usual. Era comum encontrar: "domingo próximo a tourada terá lugar", frases prontas agilizavam o processo de edição. Isso não tira de contexto, todavia, o que queremos destacar, ou seja, para os leitores dos jornais, deveria parecer sempre uma novidade na urbe e, ao que as fontes indicam, realmente era.

As deficiências na qualidade das touradas - ou pela ausência de bravios animais ou por sortes mal executadas - eram óbices recorrentes, destacados pelas pesquisas brasileiras sobre a temática (MELO, 2017). Conforme Santos e Melo (2014, p. 08) “a falta de gado adequado" era um dos problemas costumeiros na história da prática no País. Percebemos uma estratégia comum na trajetória das touradas: "o incentivo às polêmicas, que garantia uma publicidade extra”. (ROCHA JUNIOR; MELO (2016, p. 200). Como exemplo, temos que, para sanar o "logro das touradas de domingo passado por não ter se encontrado touros bravios", o periódico anunciava "ser bem reparada pela função anunciada para o dia de hoje". (O PROPULSOR, n. 07, p. 02, 29 nov. 1896).

O periódico feirense, ao mesmo tempo em que enfatizava a falta de qualidade de algumas apresentações, valorizava a tourada que se avizinhava, informando que não faltou empenho à produção do novo espetáculo tauromáquico, ao ponto de descrever a maneira como um dos touros veio conduzido para o redondel "amarrado com sete cordas e acompanhado por seis bons vaqueiros." (O PROPULSOR, n. 07, p. 02, 29 nov. 1896). Conforme Santos e Melo (2014, p.19), “os touros seguiam sendo um problema - não havia no Brasil criação de gado com características adequadas para as corridas - uma das saídas era dar notoriedade a um animal 
reconhecido (ou assim apresentado) pela ferocidade." Segundo esses autores, a adoção de um formato empresarial impunha à manutenção da prática a satisfação da assistência, permitindo, assim, o comparecimento nas funções vindouras.

Outro artifício comentado por esses mesmos autores: "o incremento da possibilidade de participação do público" foi pouco notado nas touradas de Feira de Santana. Apenas a diferenciação de lugares com "direito a assento", criando espaços de distinção social (O PROPULSOR, n. 07, p. 04, 29 nov. 1896). Diferentemente de outras cidades que experimentaram as touradas, não identificamos cobrança de bilhetes mais acessíveis para crianças; funções com parte da renda destinada à filantropia; e nem mesmo algumas atrações diferenciadas como presença de toureiras profissionais ou participação de amadores desafiados a correr touros em busca de premiações em dinheiro presas ao corpo dos próprios animais. Todas essas estratégias visavam a maximizar os lucros.

E pelo visto, tiveram êxito. Em nota do O Propulsor, falando da "Diminuta, escassa mesmo" presença de público em "nosso theatro", o articulista acaba por compará-lo aos espectadores que frequentam as touradas, afirmava: "Entretanto, poucos são os divertimentos públicos que se destacam na Feira. E a fallar, sem rebuço, vimos, aqui, ha poucos dias, uma celebre tourada, que mal trabalhava, e pessimamente divertia-nos, com numerosa enchente, até em tardes chuvosas." (O PROPULSOR, n.12, p. 02, 01 jan. 1897).

Talvez o sucesso de público deste divertimento tenha provocado o breve aparecimento de uma nova temporada. Em maio de 1897, menos de seis meses depois das últimas touradas, a despeito "da falada crise e falta de dinheiro" presente "actualmente nesta cidade", além de duas companhias de circo, "uma companhia de toureadores hespanhoes" armou seu redondel na cidade em lugar não informado. A nota afirmava que "Ze-povo" estaria sempre pronto "a dar as merecidas vaias nos «farpeadores» do meia-cara." (O PROPULSOR, n.30, p. 01, 09 maio 1897). Mais uma vez uma empresa oriunda da Península Ibérica e toureiros espanhóis. Outra faceta das touradas é destacada, não mais o encorajamento aos lidadores, evidencia-se a torcida pelos animais toureados assim como salientado em alguns estudos. (MELO, 2017).

No segundo semestre do ano de 1898, houve sinais de um possível retorno de "los toros" a desfilar pela urbe. Um pequeno comunicado anunciava: "Consta-nos que brevemente teremos n'esta cidade uma companhia de touradas." (O PROPULSOR, n. 96, p. 02, 14 ago. 1898). De maio a julho de 1898, uma companhia de tauromaquia realizou suas funções "no antigo Derby Club" na cidade de Salvador (JORNAL DE NOTÍCIA,n. 5509, p. 02, 18 maio 1898; JORNAL DE NOTÍCIA, n. 5555, p. 02, 16 jul 1898). Essa mesma empresa de toureios, provavelmente, 
se deslocaria para Feira de Santana, contudo não encontramos evidências posteriores da presença desse circo de touros ou de qualquer outro naquele ano.

Tal acontecimento traduzia-se em atividade dependente de público para seu financiamento; nesse sentido, também, de uma qualificada divulgação. Um dos melhores caminhos seria a propaganda nos periódicos locais. Usava-se como recurso a construção de narrativas de valorização por meio de crônicas exibidas nos órgãos de imprensa associadas aos anúncios publicitários; outras vezes, como já assinalado, uma ênfase na ausência de qualidade dos espetáculos, objetivando valorizar as touradas subsequentes; entre outras estratégias.

Abrangendo a última década do XIX, não localizamos nos periódicos notícias adicionais sobre nenhuma outra Praça de Touros instalada no Jockey Club Feirense ou em qualquer distinto logradouro da cidade. Na verdade, só teríamos novidades no século que se avizinhava.

\section{As touradas feirenses do início do XX}

Nos primeiros anos da nova centúria, 30 de abril de 1905, um domingo, véspera da Feira do Gado, mais uma vez um Circo de Touros surge na cidade, "pavilhão armado ao Campo General Câmara" e, na "Estréia", "trabalhos de tauromachia" desenvolvidos pelo toureador de nacionalidade espanhola Manoel Ruiz Composto (MELLO; BRITO, 2018, p 31). Detalhes desse espetáculo são pouco conhecidos. No mesmo período, entre 1904 e 1908, existem relatos de touradas realizadas em alguns largos na cidade de Salvador (ROCHA JUNIOR; MELO, 2016).

No início do século, não localizamos notícias de atividades desenvolvidas pelo Jockey Club Feirense, estava, provavelmente, desativado. O espaço era nomeado pela impressa de "antigo hyppodromo" e já era utilizado como ground por um time de futebol local ( $O$ PROGRESSO, n. 410. p. 01, 22 dez. 1907). Organizavam-se as touradas em local não institucionalizado, uma área no Campo General Câmara (Figura 4). Exatamente o local em que eram negociados os animais, conhecido por Campo do Gado - na realidade, seu nome mais popular. Seria o palco destinado ao retorno do espetáculo silenciado na centúria precedente. 
Figura 4: Campo General Câmara, o Campo do Gado

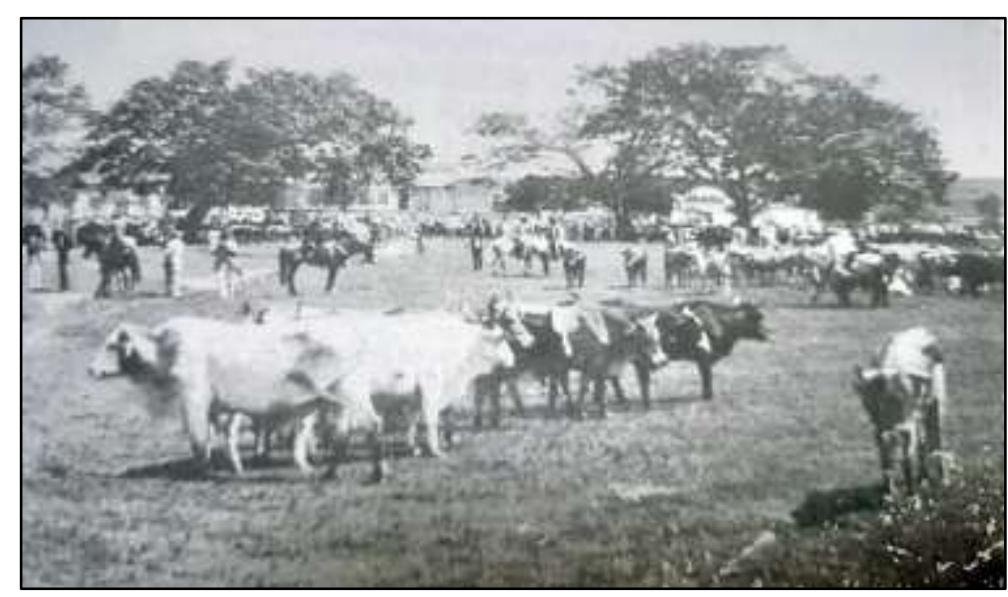

Fonte: Oliveira (2016, p. 107).

A imagem traduz um período posterior às matérias acerca das touradas realizadas naqueles momentos iniciais do século $\mathrm{XX}$, um retrato trazendo o contexto e "alguns personagens" provavelmente dos anos finais de 1920. Permaneciam os bois; ausentes os toureiros. Evidenciavam-se os vaqueiros fundamentais no transporte dos animais em grandes distancias pelo sertão e na própria lida nas fazendas, mas que foram ganhando espaço forjando um outro divertimento na cidade: a vaquejada (SIMÕES, 2007; CAVALCANTI; CASTRO JÚNIOR, 2019). Em um tempo que excede a pesquisa, junho de 1939, touradas são registradas no turno vespertino em logradouro situado em parte desse antigo campo (aproximadamente o mesmo local da fotografia), a "praça D. Pedro II" (Folha do Norte, n. 1613, 08 jun. 1940).

Construir redondel momentâneo ou perene em largos foi prática presente em algumas distintas urbes brasileiras. Em algumas vezes, espaços centralizados, outras vezes, lugares contíguos ao traçado urbano orgânico. Esse caso (o segundo) se aplicava àquela arena. Precisamente no mesmo espaço, seguiam semanalmente as tradicionais Feiras de Gado, uma das maiores de todo o Nordeste do Brasil (POPPINO, 1968) - um lugar de encontro de sertanejos, vaqueiros, fazendeiros, magarefes, pessoas vindas de povoados vizinhos e de rincões distantes (SIMÕES, 2007).

Esses espaços eram comumente chamados pela imprensa brasileira da época de Circos de Touros. No caso descrito, deslocando apenas os artistas de regiões mais longínquas, visto que os "touros" (na verdade bovinos), como pudemos constatar na pesquisa, faziam pequenos percursos saídos da própria região. Bastante diferente de Portugal, Espanha, e mesmo algumas regiões do Brasil, onde existiam arenas destinadas a temporadas tauromáquicas. A organização era local, vindo os toureiros sob contrato individual, e os touros, de outras regiões ou de ganadarias locais (MARTÍNEZ, 2013; SARGES, 2010; DIAS et al., 2019). 
No período estudado, não encontramos outras formas de registro sobre as touradas na urbe e também não topamos fotografias dos espetáculos. Temos, apenas, uma representação mimética da presença das touradas (Figura 5) na Festa do Vaqueiro, relatando o que se vivia em meados de 1960, igualmente o passado dessa prática em paisagens feirenses, provavelmente, também retratada por uma memória coletiva (HALBWACHS, 2013).

\section{Figura 5 - Gravura de uma tourada feirense}

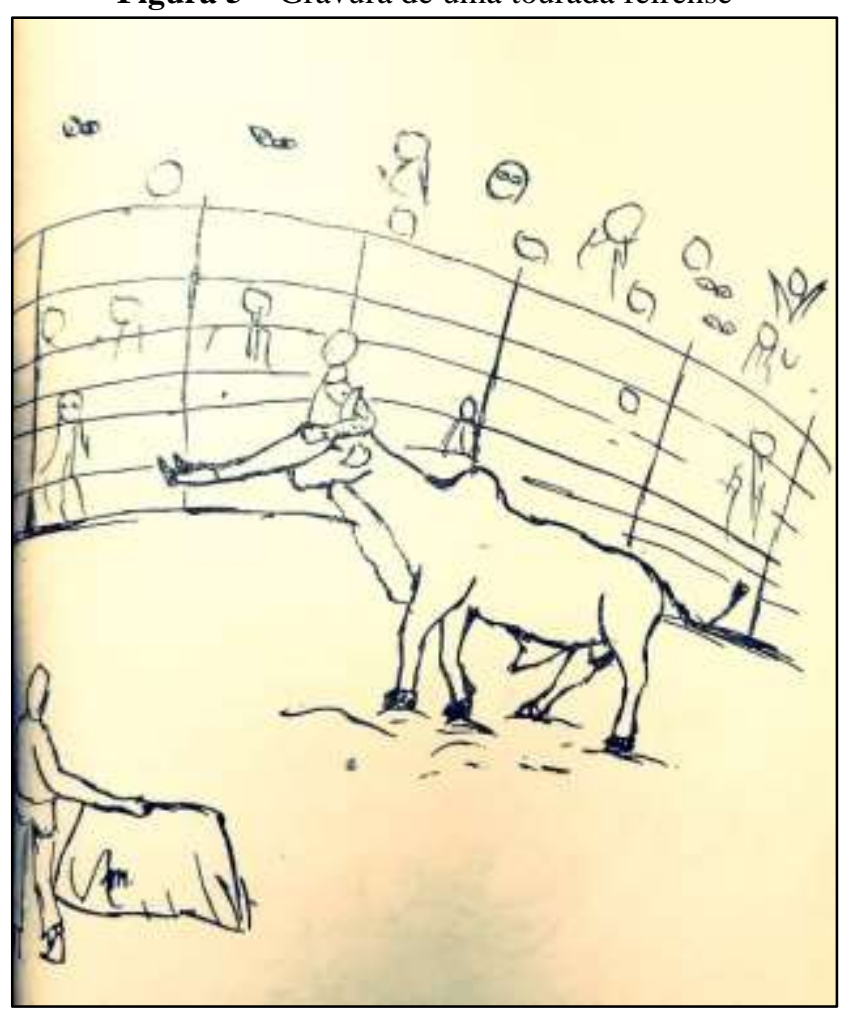

Fonte: MACHADO, Franklin de C. Feira de Santana-Álbum. São Paulo: Cacimbinha, 1966, p. 97.

Machado (1966, p. 74) dizia que as corridas de touros eram "diferentes" naquele momento, pois havia "o ingrediente da comicidade" com toureiro-palhaço e inexistia da morte dos animais.

\section{Considerações Finais}

Como vimos, as touradas alcançaram diversos sertões brasileiros ainda no século XIX, pequenos povoamentos, localidades que possivelmente reuniam algumas condições de receber tais espetáculos, possuindo um mercado de entretenimento em desenvolvimento e uma estrutura logística de apoio, tendo como exemplo, o trem. Feira de Santana foi mais um desses rincões. 
Assim como em outros divertimentos que aportaram à cidade, o transporte ferroviário e fluvial tivera implicação significativa na interiorização da tauromaquia.

Nos espetáculos tauromáquicos feirenses, identificaram-se toureiros profissionais, comprovadamente, espanhóis e ausência de toureiros de outras nacionalidades e toureadoras. É possível a presença de portugueses, comuns em diversas quadrilhas de tauromaquia. Sobre as mulheres, sabemos que elas se fizeram presentes na execução das touradas em outras localidades pelo País, porém em número reduzido.

Referente ao outro elemento imprescindível para esses espetáculos: os animais que seriam lidados. Conforme as fontes, assim como aparece em outras pesquisas brasileiras, bois selecionados vinham de fazendas da região para compor as funções realizadas em Feira de Santana, não havendo indícios da participação de touros de raça brava - especializados em tourear - nos redondéis erguidos na urbe.

Apenas existiram arenas armadas provisoriamente em Feira de Santana, às vezes, em espaço já projetado, o hipódromo do Jockey Club, outras épocas, construídas em áreas abertas contíguas ao traçado urbano, como o Campo do Gado. Sucederam eventos que não fizeram diferenciação etária ou de gênero nos valores das entradas do espetáculo, porém ocorreu distinção social com a comercialização de variados tipos e preços de ingresso.

Não localizamos muitas fontes que abordaram a temática das touradas no Município. Inexiste evidência de que festas de touros compuseram uma tradição popular feirense. As experiências relatadas, em princípio, não fizeram parte de uma programação local de festejos referentes à Nossa Senhora Sant'Anna, Padroeira do Município ou a qualquer outra festa religiosa ou popular.

Chegamos a essa conclusão exatamente pela ausência de mais ocorrências no recorte temporal proposto nos periódicos consultados depois da análise empreendida. Provavelmente uma novidade na cidade na última década do século XIX, de outro modo, assim como se procedeu em diversas regiões do Brasil, inclusive nos sertões, se expressou como um divertimento mercantilizado, exibido de modo esporádico por companhias tauromáquicas itinerantes.

\section{Referências bibliográficas}

AMARAL, Daniel Venâncio de Oliveira; DIAS, Cleber. Nos trilhos do lazer: entretenimento urbano e mercado de diversões em Divinópolis, Minas Gerais, 1890-1920. Revista de História Regional 22(2): 237-261, 2017.

AMAZONAS, Manaus, n. 141, p. 01, 08 jul. 1893. 
BAHLS, Aparecida Vaz da Silva. O verde na metrópole: a evolução das praças e jardins em Curitiba (1885-1916). 1998. Dissertação (Mestrado em História) - Setor de Ciências Humanas, Letras e Artes, Universidade Federal do Paraná, Paraná, 1998.

BIBBÓ, Caroline Bertarelli. Divertimentos em Ouro Preto no final do século XIX. 2017. Dissertação (Mestrado em Estudos do lazer) - Escola de Educação Física, Fisioterapia e Terapia Ocupacional, Universidade Federal de Minas Gerais, 2017.

BOAVENTURA, Eurico Alves. A Paisagem Urbana e o Homem. Editora UEFS, 2006.

BRASIL. Directoria Geral de Estatistica. Recenseamento do Brasil (Realizado em 1 de Setembro de 1920). Vol. IV, $4^{\text {a }}$ Parte. Rio de Janeiro: Typ. da Estatistica, 1926.

BRITO, Carlos Alberto; OLIVEIRA, Arcênio José (org.). Memórias: periódicos feirenses 1877/1888. Fundação Senhor dos Passos, Núcleo de Preservação da Memória Feirense, 2007. CAPUCHA, Luís. Festas de touros na Península Ibérica: uma leitura sociológica. In: MELO, Victor Andrade de (org.). "Pois temos touros": touradas no Brasil do século XIX. Rio de Janeiro: 7Letras, 2017.

CASCUDO, Luís da Câmara. Vaqueiros e cantadores. São Paulo: Global, 2005.

CAVALCANTI, Adriana Priscilla Costa; CASTRO JÚNIOR, Luís Vitor. Boi na pista!: sociabilidade, esporte e lazer na Princesa do Sertão. Feira de Santana; UEFS Editora, 2019.

CORREIO PARAENSE, Belém, n. 171, p.01, 27 nov. 1892.

COSTA, Lívia Gozzer. Capitães da Feira e outras crianças: a infância pobre e abandonada de Feira de Santana entre 1879 e 1945. 2013. Dissertação (Mestrado em História) Universidade Estadual de Feira de Santana, Feira de Santana, 2013.

CUNHA, Nayara Fernandes de Almeida. Os coronéis e os outros: sujeitos, relações de poder e práticas sociais em Feira de Santana (1907-1927). 2013. Dissertação (Mestrado em História) - Universidade Estadual de Feira de Santana, Feira de Santana, 2013.

DIÁRIO DA BAHIA, Salvador, n. 249, p. 02, 07 nov. 1889.

DIARIO DO POVO, Salvador, n.17, p. 01, 24 maio 1889.

DIAS, Cleber. Mercantilização do Lazer no Brasil. Licere, Belo Horizonte, v.21, n.2, jun/2018. DIAS, Douglas da Cunha; MATOS, Lucília da Silva; BAHIA, Mirleide Chaar; PINHEIRO, Welington da Costa; OLIVEIRA, Aline da Silva. Tourada: primórdio do esporte em uma Belém do Pará sob os acenos da modernidade (1870 a 1910). In: MATOS, Lucília da Silva; BAHIA, Mirleide Chaar (org.). Política pública, memória e diversidade nas práticas de esporte e lazer no estado do Pará. Belém: Paka-Tatu, 2019.

ESTADO DO PARÁ, Belém, n. 1077, p. 04, 25 mar. 1914.

FEIJÓ, Ivan Luiz Chaves. Tauromaquia e identidade: significados sociais e políticos do toureio a pé na Espanha do século XVIII. Anais... 30 Simpósio Nacional de História - História e o futuro da educação no Brasil, Recife-PE, 2019. Disponível em: https://www.snh2019.anpuh.org/resources/anais/8/1554406494_ARQUIVO_TauromaquiaeId entidadeANPUH2019trabalhoparaapresentacao.pdf . Acesso em: 13 ago. 2020.

FOLHA DO NORTE, Feira de Santana, n.2036, p. 02, 17 jul.1948.

FOLHA DO NORTE, Feira de Santana, n. 1613, 08 jun. 1940.

FOLHA DO NORTE, Feira de Santana, n. 1607, p. 01, 27 abr. 1940

FOLHA DO NORTE, Feira de Santana, n. 1492, 12 fev. 1938

FOLHA DO NORTE, Feira de Santana, n. 280, p. 01, 26 jul.1914.

GAZETA DE NOTÍCIAS, Rio de Janeiro, n. 80, p. 08, 20 mar. 1892.

HALBWACHS, Maurice. A memória coletiva. 2 ed. São Paulo: Centauro, 2013.

IBGE. População nos Censos Demográficos, segundo os municípios das capitais 1872/2010. 2010. Disponível em: https://censo2010.ibge.gov.br/sinopse/index.php?dados=6 . Acesso em: 12 fev. 2020.

JORNAL DE NOTÍCIA, Salvador, n. 5509, p. 02, 18 maio 1898.

JORNAL DE NOTÍCIA, Salvador, n.5555, p. 02, 16 jul. 1898. 
JORNAL DE NOTÍCIA, Salvador, n. 3791, p. 03, 16 jul. 1892. JORNAL DE NOTÍCIA, Salvador, n. 3771, p. 01, 20 jun. 1892. JORNAL DO COMERCIO, Rio de Janeiro, n.115, p. 01, 26 abril de 1909.

KARLS, Cleber Eduardo; MELO, Victor Andrade. Tradição e modernidade: as touradas na Porto Alegre do século XIX. História Unisinos, São Leopoldo, v. 18, n. 2, p. 352-363, maio/ago. 2014.

KARLS, Thaina Schwan; MELO, Victor Andrade de. Novas dinâmicas de lazer: as fábricas de cerveja no Rio de Janeiro do século XIX (1856-1884). Movimento, Porto Alegre, v. 24, n. 1, p. 147-160, jan./mar. 2018.

LAGEDINHO, Antônio do. A Feira na década de 30: memórias. Feira de Santana: [s.n.], 2004.

LIMA, Lizandra de Souza. Percepções históricas sobre o lazer e a educação nas práticas de sociabilidade em Alagoinhas-BA. 2018. Dissertação (Mestrado em Educação) - Faculdade de Educação, Universidade Federal da Bahia, Salvador, 2018.

LUCA, Tânia Regina de. História dos, nos e por meio dos periódicos. In: PINSKY, Carla Bassanezi (org.). Fontes históricas. São Paulo: Contexto, 2019. p. 111-153.

MACHADO, Franklin de C. Feira de Santana-Álbum. São Paulo: Cacimbinha, 1965.

MARTÍNEZ, Antonio Luis López. El mercado taurino en los inicios de la tauromaquia moderna, Sevilla, Fundación Real Maestranza de Caballería de Sevilla/Fundación de Estudios Taurinos, Universidad de Sevilla, 2013.

MELLO, Carlos Alberto Almeida; BRITO, Carlos Alberto Oliveira (org.). Inauguração da Biblioteca Pública Municipal da Feira de Santana. Feira de Santana: Fundação Senhor dos Passos, Núcleo de Preservação da Memória Feirense, 2020.

MELLO, Carlos Alberto Almeida; BRITO, Carlos Alberto Oliveira (org.). Memórias: Arnold Ferreira da Silva. Feira de Santana: Fundação Senhor dos Passos, Núcleo de Preservação da Memória Feirense, 2018.

MELO, Victor Andrade de (org.). "Pois temos touros": touradas no Brasil do século XIX. Rio de Janeiro: 7Letras, 2017.

MELO, Victor Andrade de. "Pois temos touros?": as touradas no Rio de Janeiro do XIX (18401852)”. Análise Social, 215, 1 (2. $\left.{ }^{\circ}\right)$, p. 382-404, 2015.

MELO, Victor Andrade de. Uma diversão adequada? As touradas no Rio de Janeiro do século XIX (1870-1884). História (São Paulo), v.32, n.2, p. 163-188, jul./dez. 2013b.

MELO, Victor Andrade de. As touradas nas festividades reais do Rio de Janeiro colonial. Horizontes Antropológicos, Porto Alegre, v. 19, n. 40, p. 365-392, 2013 a.

MELO, Victor Andrade de. Das touradas às corridas de cavalo e regatas: primeiros momentos da configuração do campo esportivo no Brasil. In: PRIORE, Mary Del; MELO, Victor Andrade de (org.). História do esporte no Brasil: do Império aos dias atuais. São Paulo: Editora Unesp, 2009. p. 35-70.

MELO, Victor Andrade de. Dicionário do esporte no Brasil no final do século XIX e início do século XX. Campinas: Autores Associados, 2007.

O COMMERCIO DE SÃO PAULO, São Paulo, n. 2827, p. 04, 25 jan.1902.

O CRUZEIRO. Rio de Janeiro, n. 15, p. 27, 23 jan.1960.

O DEMOCRATA, Belém, n. 107, p. 03, 13 maio 1893.

O MUNICÍPIO, n. 132, p. 02, [s. d.], 1893.

O PROGRESSO, Feira de Santana, n.04, p. 02, 10 ago. 1882.

O PROGRESSO, Feira de Santana, n. 410. p. 01, 22 dez. 1907.

O PROPULSOR, Feira de Santana, n.192, p. 03, 17 jun. 1900.

O PROPULSOR, Feira de Santana, n.164, p. 01, 03 dez. 1899.

O PROPULSOR, Feira de Santana, n.159, p. 01, 29 out. 1899.

O PROPULSOR, Feira de Santana, n. 96, p. 02, 14 ago. 1898. 
O PROPULSOR, Feira de Santana, n.85, p. 01, 29 maio 1898.

O PROPULSOR, Feira de Santana, n.84, p. 02, 22 maio 1898.

O PROPULSOR, Feira de Santana, n.78, p. 03, 10 abr. 1898.

O PROPULSOR, Feira de Santana, n.65, p. 01, 09 jan. 1898.

O PROPULSOR, Feira de Santana, n. 35, p. 02, 12 de jun. 1897.

O PROPULSOR, Feira de Santana, n.30, p. 01, 09 maio 1897.

O PROPULSOR, Feira de Santana, n.12, p. 02, 01 jan. 1897.

O PROPULSOR, Feira de Santana, n. 08, p. 04, 05 dez. 1896.

O PROPULSOR, Feira de Santana, n. 07, p. 04, 29 nov. 1896.

O PROPULSOR, Feira de Santana, n.06, p. 04, 20 nov. 1896.

OLIVEIRA, Clovis Ramaiana Moraes. Canções da cidade amanhecente: Urbanização, Memória e Silenciamentos em Feira de Santana, 1920-1960. Salvador: EDUFBA, 2016.

OLIVEIRA, Clovis Ramaiana Moraes. De empório a Princesa do Sertão: Utopias civilizadoras em Feira de Santana (1893-1937). 2000. Dissertação (Mestrado em História) Faculdade de Filosofia e Ciências Humanas, Universidade Federal da Bahia, Salvador, 2000.

POPPINO, Rollie. Feira de Santana. Bahia. Editora Itapuã. 1968.

ROCHA JUNIOR, Coriolano Pereira da; MELO, Victor Andrade de As touradas na Cidade da Bahia: transições na dinâmica pública soteropolitana. História e Perspectivas, Uberlândia, n. 54, p.189-211, jan./jun. 2016.

RODRIGUES, Marilita Aparecida Arantes. Constituição e enraizamento do esporte na cidade: uma prática moderna de lazer na cultura urbana de Belo Horizonte (1894 - 1920). 2006. Tese (Doutorado em História) - Faculdade de Filosofia e Ciências, Universidade Federal de Minas Gerais, Belo Horizonte, 2006.

SANTOS, Aline Aguiar Cerqueira dos. Diversões e civilidade na "Princesa do Sertão" (1919-1946). 2012. Dissertação (Mestrado em História) - Universidade Estadual de Feira de Santana, Feira de Santana, 2012.

SANTOS, Flávia; MELO, Victor. Entre o rural e o urbano: as touradas na São Paulo do século XIX (1877-1889). Revista IHGB, Rio de Janeiro, ano 175, n. 463, p. 39-69, abr./jun. 2014.

SARGES, Maria de Nazaré. "Tauromachia", Tauromania: migrantes galegos e práticas culturais em Belém. In: Cristina Donza Cancela; Rafael Chambouleyron (org.). Migrações na Amazônia. Belém: Açaí, v. 2, 2010. p. 55-66.

SARGES, Maria de Nazaré. O Colyseu: arena de touros e toureiros do além-mar - Belém do Pará (1894-1900). In: MATOS, Maria Izilda; SOUSA, Fernando de; HECKER, Alexandre (orgs.). Deslocamentos e histórias: os portugueses. Bauru: EDUSC, 2008. p. 321-335.

SILVA, Aldo José Moraes. Natureza sã, civilidade e comércio em Feira de Santana: elementos para o estudo da construção de identidade social no interior da Bahia (1833-1937). 2000. Dissertação (Mestrado em História) - Faculdade de Filosofia e Ciências Humanas, Universidade Federal da Bahia, Salvador, 2000.

SILVA, Reginaldo Carvalho da. Dionísio pelos trilhos do trem: circo e teatro no interior da Bahia, Brasil, na primeira metade do século XX. 2014. Tese (Doutorado em Artes Cênicas.) Escola de Teatro, Universidade Federal da Bahia, Salvador; Ècole Doctorale Lettres, Langues, Spectacles, Université Paris Ouest La Défense, Paris, 2014.

SIMÕES, Kleber José Fonseca. Os homens da Princesa do Sertão: modernidade e identidade masculina em Feira de Santana (1918-1928). 2007. 138f. Dissertação (Mestrado em História) - Faculdade de Filosofia e Ciências Humanas, Universidade Federal da Bahia, Salvador, 2007. SOARES, Priscila Gonçalves. Práticas corporais e diversão em Juiz de ForalBH: o discurso do jornal O Pharol (1876 - 1915). 2010. Dissertação (Mestrado em Educação) - Universidade Federal de Juiz de Fora, Juiz de Fora, 2010.

VIEIRA, David Durval Jesus. Sensibilidade (in)civilizada: poder público, animais de tração e touradas em Belém (1897-1911). Revista Espacialidades, v. 7, n. 1, p. 148-170, 2014. 
XIMENES, Maria Alice. Corpo e roupa: território da existência e da cultura: reflexões para o redesenho do corpo feminino no século XIX, 2004. Dissertação (Mestrado em Artes) - Instituto de Artes, Universidade Estadual de Campinas, Campinas, 2004 